\title{
THE CHEMICAL CHARACTERISTICS AND ANTIOXIDANT ACTIVITY OF STARCH FROM SAGO BARUK PITH (Arenga microcarpha)
}

\section{KARAKTERISTIK KIMIA DAN AKTIVITAS ANTIOKSIDAN PATI SAGU BARUK (Arenga microcarpha)}

\author{
Lidya Irma Momuat $^{1 *}$, Edi Suryanto ${ }^{1}$, Sri Sudewi $^{2}$ \\ ${ }^{1}$ Department of Chemistry, FMIPA Sam Ratulangi University, Manado \\ ${ }^{2}$ Department of Phamacy FMIPA Sam Ratulangi University, Manado \\ *email: 1momuat@yahoo.com \\ Received 26 April 2016; Accepted 27 October 2016; Available online 29 November 2016
}

\begin{abstract}
Sago Baruk (Arenga microcarpha) is one of endemic crop type of Archipelago of Sangihe Talaud, North Sulawesi and potential as source bioactivities including an antioxidant. The objectives of this research were to determine the chemical characteristics and antioxidant activity of starch sago baruk which was sequentially extracted with water and filtrate. The sago trunks pith was sequentially extracted with water and filtrate at room temperature for 1 hour. After that, the starch of sago baruk were analyzed for their chemical composition (moisture, fat, protein, ash crude fiber and carbohydrate) and total phenolic and tannin condensed content. Antioxidant activity of each sago flour were evaluated in 1,1-diphenyl-2-picrylhydrazyl (DPPH) radical scavenging and total antioxidant capacity. After that, the starch was characterized by IR spectroscopic technique. The sequential extraction result indicated percentage yield of starch I and starch II were $41.39 \%$ and $38.21 \%$. The chemical characteristics of starch I revealed that percentage protein, ash, crude fiber and fat were below $1 \%$ than starch II especially protein and fiber crude. The starch I had highest total phenolic and tannin condensed content than starch II and starch K. The starch I also showed the highest free radical scavenging activity in 1,1-diphenyl-2-picrylhydrazyl (DPPH) radical than starch II and starch K. The result also showed that starch I has strongest total antioxidant capacity than starch II and starch $\mathrm{K}$ at all concentration level. Antioxidant activity of three starch increased with the increase in concentration of the samples. The three starch showed of hidroxy $(\mathrm{OH})$, carbonyl $(\mathrm{C}=\mathrm{O})$, ether $(\mathrm{C}-\mathrm{O})$ and aliphatic group $(\mathrm{C}-\mathrm{C})$. It is concluded that starch sago baruk especially the starch I are very rich in antioxidant substituents.
\end{abstract}

Keywords: antioxidant, extraction, sago baruk, starch

ABSTRAK
Sagu baruk (Arenga microcarpha) merupakan salah satu jenis tanaman pangan endemik di
Kepulauan Sangihe Talaud, Sulawesi Utara dan berpotensi sebagai sumber bahan bioaktif termasuk
antioksidan. Tujuan penelitian ini adalah untuk menentukan karateristik kimia dan aktivitas
antioksidan pati sagu baruk yang diekstraksi secara sekuensial dengan akuades dan filtrat. Empelur
batang sagu diekstraksi secara sekuensial dengan akuades dan filtrat selama 1 jam. Setelah itu, pati
sagu baruk dikarakterisasi kimia (air, abu, protein, lemak, serat kasar, karbohidrat) dan dianalisis
kandungan total fenolik dan tannin terkondensasi. Aktivitas antioksidan dari pati sagu baruk
dievaluasi dengan penangkalan radikal bebas difenil pikril hidrazil (DPPH) dan kapasitas total
antioksidan. Setelah itu, pati dikarakterisasi dengan teknik spektrofotometer IR. Hasil ekstraksi
secara sekuensial menunjukkan bahwa pati I dan pati II memiliki persentase rendemen adalah
41,39\% and 38,21\%. Karateristik kimia pati I memperlihatkan bahwa persentase protein, abu, serat
kasar dan lemak adalah dibawah $1 \%$ daripada pati II terutama protein dan serat kasar. Pati I
memiliki kandungan total fenolik dan tanin terkondensasi lebih tinggi daripada pati II dan pati K.
Pati I menunjukkan aktivitas penangkal radikal bebas DPPH paling tinggi daripada pati I dan pati
K. Hasil ini juga menunjukkan bahwa pati I mempunyai kapasitas total antioksidan paling kuat
daripada pati II dan pati K pada semua tingkat konsentrasi. Aktivitas antioksidan ketiga jenis pati


sagu baruk meningkat dengan peningkatan pada konsentrasi sampel. Analisis IR pada pati I dan pati II menunjukkan adanya gugus hidroksi $(\mathrm{O}-\mathrm{H})$, gugus karbonil $(\mathrm{C}=\mathrm{O})$, gugus eter $(\mathrm{C}-\mathrm{O})$ dan gugus alifatik (C-C). Hasil penelitian ini menyimpulkan bahwa pati sagu baruk terutama pati I sangat kaya fitokimia antioksidan.

Kata kunci: antioksidan, ekstraksi, sagu baruk, pati

\section{BACKGROUND}

Sago baruk (Arenga microcharpha Beccari) is an endemic edible plant that grow in Sitaro, Sangihe, Talaud regency and for a long time have been used by local society as rice instead. Sago baruk was used as a potential source of starch and functional food so that be able to alternative foods. Sago baruk plant grows dry land, while sago Metroxylon grows in wet lands. The processing sago baruk be starch no different from processing sago Metroxylon found in many other areas.

A few research has been done either improved the characteristic of starch and extraction method of sago metroxylon. The frequent research was did focussed on carbohydrates content and starch modified. The research for improves the characteristic starch of sago has been carried out by acetylation modification method and cross-linking and hydroxypropyl (Teja, 2008; Polnaya, 2009). The different research were also carried out for repairing both extraction method are mechanically or chemically as research has been done by Manan (2011), by optimazing extraction of sago starch using large grate drum, while chemically, Lay \& Indrawanto (2013), did improve the yield and quality of sago starch with immersion technique using potassium bromic and ascorbic acid. According to Momuat et al. (2015) that phenolic and flavonoid total content indicated that dry sago baruk higher compared fresh sago flour of baruk wet while tannin condensed content do not show difference. Result of examination of antioxidant activity indicated that fresh sago baruk having higher DPPH free radical scavenging activity compared to dry sago baruk. Furthermore, Suryanto \& Papilaya (2013) reported that the sago Metroxylon type of sago ihur has antioxidant activity and phenolic content and flavonoid higher than sago types of Molat, Tuni, Duri itam, Kaang and Makanaru while sago types Molat contains higher tannin condensed.

Natural phenolic compounds derived from edible and non edible plants has its own appeal and widely spread and is found in plant tissues and has been claimed to have a role as an antioxidant. Phenolic compounds in plants are closely related to antioxidant activity. Based on the research that has been carried out above, it can be said that research on sago done for the improvement of the quality of the extraction method and sago in terms of carbohydrate. However, research on the effects of sago pith extraction to increase the functional value of the sago starch, especially the antioxidant phytochemical content throughout the known is still very limited. This study aims to extract starch from sago baruk pith, chemical characteristics and evaluate the antioxidant activity of starch baruk pith.

\section{EXPERIMENTAL SECTION}

\section{Equipments}

The used equipments are knife, glassware, micropipette, vortex, mixer,blender, analytical balances, oven, rotary evaporator, spectrophotometer UVVis (Genesis 10) and FT-IR (Shimadzu Prestique 21).

\section{Materials}

The material used in this research are sago baruk crop with harvest about 9 years-old obtained from Sangihe regency, North Sulawesi. The chemicals used are methanol, ethanol, $n$-hexane, chloride acid, sulfuric acid, potassium sulfate, anhydrous sodium acetate, sodium carbonate, iron (II) sulfate, Folin- 
Ciocalteu reagent obtained from Merck (Darmstadt, Germany). Catechins, 2,4,6tri (pyrydyl) -s-triazine (TPTZ) and 1,1diphenyl-2-picrylhydrazyl (DPPH) were obtained from Sigma Chemical Co. (St. Lois, MO). Gallic acid obtained from Aldrich Chemical Co. (Milwaukee, Wisconsin)

\section{Extraction of sago baruk pith}

The stem of sago baruk pith cutted into small pieces using a stainless steel knife with a size of $1 \mathrm{~cm}$. A total of $200 \mathrm{~g}$ sago baruk pith extracted with $1 \mathrm{~L}$ of distilled water and then pulverized in a blender for 5 minutes and filtering using chiffon fabric to obtain a filtrate and residues. The filtrate was subsequently allowed to stand for 1 hour to obtain sediment (starch) first. In the same way, extract the residues with filtrate from an extract of the first, second, third, fourth and fifth so that at the end of the extraction will be obtained in the form of starch combined precipitate are referred starch I.

Results precipitation in the form of wet starch is then performed in a drying oven at a temperature $50{ }^{\circ} \mathrm{C}$ for 9 hours. In the same way, extract sago baruk pith with distilled water until the fifth extraction are referred starch II. The starch yield is calculated based on the dry weight of starch and the results stored in plastic bags prior to chemical characterization, phytochemical analysis and testing for antioxidant activity.

\section{Chemical Characteristic of Sago baruk Powder}

Analysis of the chemical composition of the sago baruk starch includes analysis of moisture, ash, protein, fat, crude fiber and carbohydrate (by difference) was performed according to AOAC methods (2000).

\section{Extraction of sago baruk starch}

Five grams of sago starch put into a $250 \mathrm{~mL}$ Erlenmeyer flask which was lined with aluminum foil to avoid light, then extracted for 24 hours with $50 \mathrm{~mL}$ of $50 \%$ ethanol. After that, filtered and the filtrate is evaporated to obtain the extract sago baruk starch. Subsequently, extract stored at $5^{\circ} \mathrm{C}$ for the preparation of phytochemical analysis and testing of antioxidant activity.

\section{Determination of Total Phenolic Content}

The total phenolic content of the three sago powder extract was determined using modified Folin-Ciocalteu colorimetric method $\mathrm{Li}$ et al. (2009). Ethanolic sample solution $(0.1,1 \mathrm{mg} / \mathrm{mL})$ $\mathrm{mL}$ was added to Folin-Ciocalteu reagent $(0.1 \mathrm{~mL}, 50 \%)$ in a test tube and then this mixture vortexed for 3 minutes. After intervals of 3 minutes, two $\mathrm{mL}$ of $\mathrm{Na}_{2} \mathrm{CO}_{3}$ $2 \%$ solution was added. After incubation at room temperature for $30 \mathrm{~min}$, the mixture was kept in the dark for 30 minutes. The supernatant was measured using a spectrophotometer at $760 \mathrm{~nm}$. The standard curve was prepared using different concentrations of gallic acid and the results were expressed as gallic acid equivalents in milligrams per milligram extract.

\section{Determination of Condensed Tannin}

The content of the condensed tannin samples was determined according to the method by Suryanto et al. (2011) with minor modifications. A total of $0.1 \mathrm{~mL}$ of sample solution included in the test tube wrapped in aluminum foil, then added 3 $\mathrm{mL}$ of vanillin $4 \%(\mathrm{w} / \mathrm{v})$ in methanol and vortexed. Immediately after added $1.5 \mathrm{~mL}$ of concentrated $\mathrm{HCl}$ and vortexed again. The absorbance read at $500 \mathrm{~nm}$ after the mixture was incubated for 20 minutes at room temperature. The results are plotted against the standard curve catechin prepared in the same manner. The condensed tannin content expressed as $\mu \mathrm{g} / \mathrm{mL}$ extract.

\section{Determination of Free Radical Scavenger}


Determination of free radical activity (scavenger) from sago baruk starch extracts measured by the method $\mathrm{Li}$ et al. (2012) slightly modified. A total of 2 $\mathrm{mL}$ solutions of 1,1-diphenyl-2picrylhydrazyl (DPPH) $92 \mu \mathrm{M}$ in ethanol was added $0,5 \mathrm{~mL}$ extract sago baruk starch. The level of color reduction of the solution shows the efficiency of radical scavenger. The last five minutes of the 30 minutes, the absorbance was measured with a spectrophotometer at $517 \mathrm{~nm}$. Free radical scavenger activity was calculated as a percentage reduction of DPPH color using the equation: $100 \mathrm{x}$ (1-absorbance of the sample/ absorbance of control).

\section{Determination of Total Antioxidant}

Determination of total antioxidant determined by methods ferric reducing ability of plasma (FRAP) (SzydlowskaCzerniak et al., 2008). Measurement is carried out by taking $0.1 \mathrm{~mL}$ sago baruk starch extract dissolved in ethanol is mixed with $3 \mathrm{~mL}$ reagent FRAP in a fresh state. Then the mixture is shaken with a vortex instrument and thereafter, immediately was measured absorbance at $593 \mathrm{~nm}$ wavelength. FRAP reagent was always prepared in a fresh state by mixing $2.5 \mathrm{~mL}, 10 \mathrm{mM}$ solution of 2,4,6-tripiridils-triazine (TPTZ) in $40 \mathrm{mM} \mathrm{HCl} \mathrm{mM}$ with $2.5 \mathrm{~mL}, 20 \mathrm{~mL}$ solution of $\mathrm{FeCl}_{3} 6 \mathrm{H}_{2} \mathrm{O}$ and $2.5 \mathrm{~mL}, 0.3 \mathrm{M}$ acetate buffer at $\mathrm{pH}$ 3.6. The total content expressed as equivalent antioxidant $\mathrm{Fe}^{3}$ to $\mathrm{Fe}^{2+}$ in mol/L extract. To create a standard curve was prepared in the same way using $\mathrm{FeSO}_{4}$ solution with a concentration of between 100-1000 mol L ${ }^{-1}$.

\section{Statistica Analyzed}

Data were analyzed with computer software, SPSS version 18 (Illinois, USA) using ANOVA analysis followed by Duncan's Multiple Range Test to determine the significant differences between the carrying by $5 \%$.

\section{RESULT AND DISCUSSION}

\section{Yield Percentage}

Sago baruk pith extracted in the two treatments extraction was presented in Table 1. The highest Percentage yield obtained in the filtrate sago $(41.39 \%)$ than sago distilled water $(38.21 \%)$. The obtained percentage yield showed that the treatment of extraction technique was strongly influenced by the solvent extraction on pith sago baruk. In other words, treatment with filtrate extraction is estimated the secondary metabolites components extractable together with starch so as to contribute to the enhancement yield than sago baruk starch that extraction with water only.

\section{Chemical Characteristic}

Sago baruk stem used for the material sampled in this study is fresh path stem sago baruk with a water content of $57.18 \%$. Subsequently extracted, washed and dried to obtain sago starch that passes 65 mesh. Sago baruk starch were then characterized chemicals that include moisture, ash, protein, fat, crude fiber and carbohydrate. The results of chemical characterization of sago baruk starch presented in Table $\mathbf{1}$.

Table 1 shows that the moisture of the Starch I (sago baruk starch extracted by filtrate) did not show a difference ( $p>0.05$ ) with Starch II (sago baruk starch extracted by distilled water) but in contrast to starch $\mathrm{K}$ (commercial sago starch) are processed traditionally. Analysis of the protein content of the three types of sago starch showed that the protein content of starch $\mathrm{K}$ is no different with starch II and starch I. Sago baruk starch were found to be lower than that reported by Marianus (2014) that is equal to $1.71 \%$. Analysis of the fat levels showed similarity for all three types of starch that is equal to $0.01 \%$. Results of testing the fat content are in contrast to the results reported by Marianus (2014) that is equal to $1,40 \%$. 
Table 1. Chemical composition of Sago baruk starch

\begin{tabular}{lccc}
\hline \multicolumn{1}{c}{ Components } & Starch I & Starch II & Starch K \\
\hline Moisture (\%) & $7.87 \pm 0.11^{\mathrm{a}}$ & $7.89 \pm 0.04^{\mathrm{a}}$ & $6.75 \pm 0.35^{\mathrm{b}}$ \\
Ash $(\%)$ & $0.06 \pm 0.02^{\mathrm{a}}$ & $0.03 \pm 0.01^{\mathrm{a}}$ & $0.07 \pm 0.0^{\mathrm{a}}$ \\
Protein $(\%)$ & $1.13 \pm 0.43^{\mathrm{a}}$ & $1.27 \pm 0.33^{\mathrm{a}}$ & $1.84 \pm 0.55^{\mathrm{a}}$ \\
Fat $(\%)$ & $0.01 \pm 0.01^{\mathrm{a}}$ & $0.01 \pm 0.01^{\mathrm{a}}$ & $0.01 \pm 0.04^{\mathrm{a}}$ \\
Crude fiber (\%) & $0.79 \pm 0.05^{\mathrm{a}}$ & $2.09 \pm 12^{\mathrm{b}}$ & $2.10 \pm 0.21^{\mathrm{b}}$ \\
Carbohydrate (\%) & $90.16 \pm 0.51^{\mathrm{a}}$ & $88.73 \pm 0.19^{\mathrm{a}}$ & $88.22 \pm 0.73^{\mathrm{a}}$ \\
\hline means $(\mathrm{n}=2) \pm$ SD. Values with the same superscript letter are not statistically significant at the 5\% level
\end{tabular}

The results of measurements of the ash content of starch I, II and $\mathrm{K}$ are 0.06 ; 0.03 and $0.07 \%$ respectively. Starch I and starch II showed no difference with the type of starch K ( $\mathrm{p}<0.05)$. Ash content test result is still in the range allowed in National Standardization Agency of Indonesia (2008) is a maximum of $0.5 \%$. Crude fiber content measurement results for the three types of starch show a significant difference $(\mathrm{p}<0.05)$. Three types of crude fiber content of starch is higher than the requirements of National Standardization Agency of Indonesia, which is $0.5 \%$. This may be caused by factors of sago starch extraction process to extract the components of secondary metabolites that can contribute to an increase in crude fiber content of sago baruk powder. The measurement results by different showed that the carbohydrate of starch sago baruk type starch I $(90.16 \%)$ and starch II $(88.73 \%)$ showed also different with the starch K (88.22\%).

\section{Total Phenolic and Tannin Condensed Content}

Determination of total phenolic content was carried out to know the antioxidant potential of sago baruk starch by extraction maceration. The results of the analysis of total phenolic content starch I, II starch and starch K extract can be seen in Table 2. Table 2 shows that the total phenolic content of starch I was higher than the starch II and starch $\mathrm{K}$ as a positive control (comparison starch). The results of the analysis of the total phenolic content of starch I, II and $\mathrm{K}$ are 39.08; 24.39 and $13.38 \mathrm{mg} / \mathrm{mL}$, respectively. The high total phenolic content of starch I can be caused by extraction using the filtrate can maintain phytochemical content contained on the starch I, while starch II second to the fifth extraction using solvent water so phytochemical content contained on starch II is lower. As with the processed starch $\mathrm{K}$ traditionally with sago starch powder by washing with water flowing continuously, so the phytochemical content was wasted. The total phenolic content sago baruk starch I was larger than starch tuni (Metroxylon rumphii Martius) and lower than the sago starch Molat (Metroxylon sagus Rottbol).

The analysis result of the condensed tannin content total on starch I, II and starch $\mathrm{K}$ can be seen in Table 2. The highest condensed tannin content in the starch I that is equal to $5.91 \mu \mathrm{g} / \mathrm{mL}$ followed by starch II of $2.80 \mu \mathrm{g} / \mathrm{mL}$ and starch K of $1.19 \mu \mathrm{g} / \mathrm{mL}$.

Table 2. Total phenolic and tannin condensed content of sago baruk starch

\begin{tabular}{ccc}
\hline Sample & $\begin{array}{c}\text { Phenolic content } \\
(\boldsymbol{\mu g} / \mathbf{m L})\end{array}$ & $\begin{array}{c}\text { Tannin content } \\
(\boldsymbol{\mu g} / \mathbf{m L})\end{array}$ \\
\hline Starch I & $32.04 \pm 0.02^{\mathrm{a}}$ & $5.91 \pm 0.08^{\mathrm{a}}$ \\
Starch II & $13.37 \pm 0.01^{\mathrm{b}}$ & $2.80 \pm 0.39^{\mathrm{b}}$ \\
Starch K & $4.80 \pm 0.03^{\mathrm{c}}$ & $1.19 \pm 0.16^{\mathrm{c}}$ \\
\hline
\end{tabular}

Values are means $(n=2) \pm$ SD. Values with the same superscript letter are not statistically significant at the $5 \%$ level 
Results of testing the condensed tannin content total starch I is higher from sago starch type tuni and molat starch type Metroxylon (Suryanto \& Papilaya, 2013). From the condensed tannin content total was also showed a results in line with the results of the analysis of the total phenolic content in which starch I have a phytochemical content higher than starch II and starch K. Tannins are compounds that have a lot of presence of hydroxyl on the hydroxyl groups are plenty of tannin allows this compound more soluble in water so that the solubility of polyphenol compounds in water will grow readily soluble in the solvent extraction or washing water in the pith of sago soaked with sago starch. The main components of the condensed tannin is flavon-3-ol which these compounds including flavonoids group whose members are widespread in plants (Garcia-Salas et al., 2010). Research on the tannin has been reported that the tannins 15-30 times more effective as a peroxyl radical scavenger than simple phenolic compounds. Therefore, tannins have potential as an important free radical scavenger (Alasalvar et al., 2006).

\section{Free Radical Scavenging Activity}

Measurement the antioxidant activity of starch powder using free radical DPPH (1,1-diphenyl-2picrylhydrazyl) as the media activity test free-radical scavengers. Testing of DPPH free radical scavenger activity with spectroscopy are carried out by reacting the extract with DPPH solution. A decrease in the intensity of the color of DPPH solution as a result of the release of the hydrogen atoms of the phenolic compound to the unpaired electrons contained in the compound DPPH. DPPH radical compounds typically used as a substrate to evaluate the antioxidative activity of plant extracts. Decreased absorbance of DPPH free radical solution and followed by a color change from purple to yellow. The phenolic compounds present may have acted as free radical scavengers by their hydrogendonating ability (Shahidi et al., 2007). Figure 1 shows the activity of free-radical scavengers of the three types of sago baruk starch tested using DPPH free radicals. The test results deterrence activity of free radicals DPPH of fourth types of treatments showed that in general starch I and starch II reaches capability as free radicals scavenger at above 50\%, except for starch K.

The results of the analysis of free radical scavenger towards the three types of sago baruk powder showed that the percentage of free-radical scavengers starch I have the highest free radical scavenger of $86.50 \%$, followed by starch II of $59.31 \%$ and starch $\mathrm{K}$ of $31.24 \%$ at the same concentration.

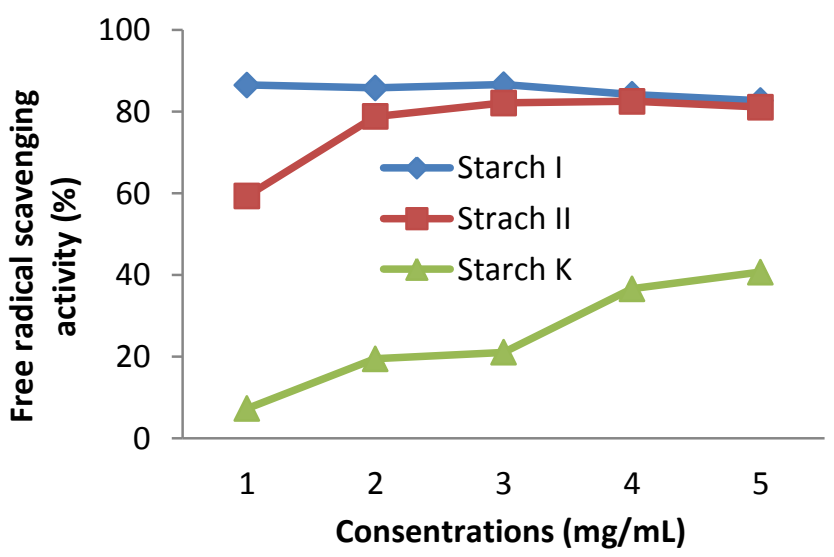

Figure 1. DPPH free radical scavenger activity of sago baruk starch in various concentration 
There is a tendency that higher concentration of sago baruk type of starch II and starch $\mathrm{K}$ given the higher activity DPPH free radical scavengers, in contrast to the type of starch sago baruk type of starch I did not show increased concentrations, but showed decreased activity DPPH free radical scavengers. This may be due to interference sago baruk starch extract color against DPPH solution color so that maximum absorbance at $517 \mathrm{~nm}$ for measuring free radical scavenger activity.

According to Barros et al. (2007), the activity of DPPH free radicals generally increases with the addition of the extract to a certain concentration, then the activity will decrease with the addition of higher concentration again. These results conclude that the activity of DPPH free radical scavenger to the three types of sago baruk starch depends on the given concentration. Activities sago baruk type starch I and starch II against DPPH free radical compared to starch $\mathrm{K}$ as positive control at all concentrations showed higher as DPPH free radical scavengers.

DPPH radical scavenging activity was observed to increase with sample concentration sigmoidally between 1 to 5 $\mathrm{mg} / \mathrm{mL}$ sample for type starch I and starch II (Figure 1). However, for our studies, a plateau was observed at concentrations of $4-5 \mathrm{mg} / \mathrm{mL}$ (starch I) and concentration of $5 \mathrm{mg} / \mathrm{mL}$ (starch II). The plateau for these studies may indicate that the DPPH radical scavenging activity of their samples reaches saturation at higher concentrations. This result is not mean that in highest concentration exhibited lower antioxidant activity. The same trend was observed in the studies by Cornago et al. (2011) on tuber samples.

Radical of DPPH is a stable free radical and accept one electron or hydrogen into a stable molecule (Alothman et al. 2009). The DPPH assay measures this capacity by monitoring the decrease in absorbance of DPPH radical as it reacts with the antioxidant $(\mathrm{AH})$. This was indicated by the color change from purple into pale yellow. When various plants extract and pure compounds (antioxidant) scavenge the free radicals by donation of a hydrogen atom $(\mathrm{H} \bullet)$ and electron (e) to form a stable DPPH-H molecule, the concentration of DPPH decreases causing a decrease in absorbance at $517 \mathrm{~nm}$. Therefore, stronger free radical scavengers cause a greater decrease in absorbance and more potential extract as an antioxidant.

\section{Total Antioxidant Capacity}

Determination of the content of total antioxidant of sago baruk starchextract in this study was conducted to test the ferric reducing ability of plasma (FRAP). FRAP method can determine the total antioxidant content of a sample based on the ability of these compounds to reduce $\mathrm{Fe}^{3+}$ to $\mathrm{Fe}^{2+}$. The intensity of the blue color of TPTZ-Fe ${ }^{2+}$ complex which is the basis for the determination of total antioxidants in FRAP methods have a maximum absorbance at a wavelength of $593 \mathrm{~nm}$ (Figure 3).

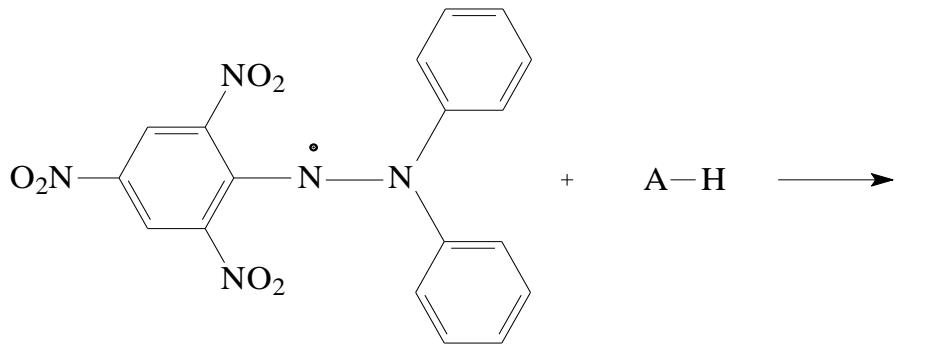

Diphenylpicrylhydrazyl (free radical) phenolic compound (purple)

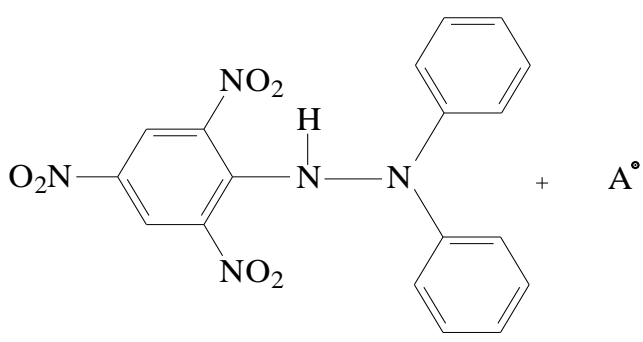

Diphenylpicrylhydrazyl (yellow)

Figure 2. Reaction between free radical $(\mathrm{AH})$ with DPPH free radical 


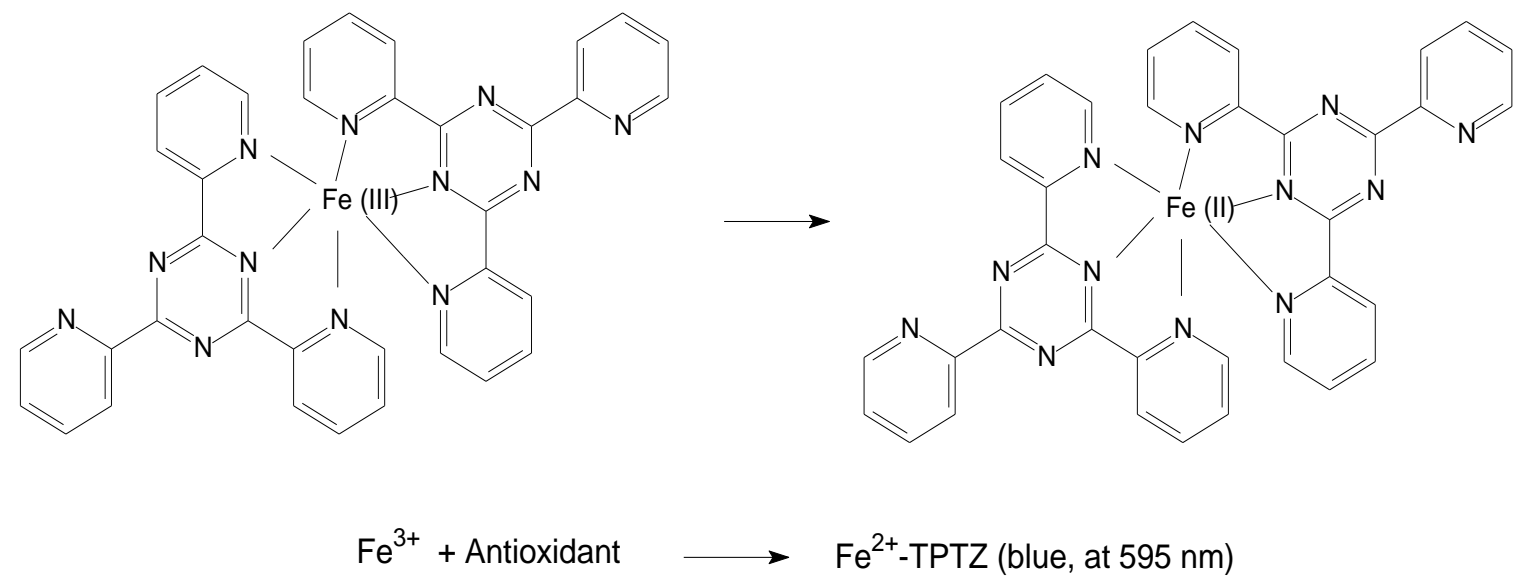

Figure 3. Reaction between antioxidant compounds with TPTZ- $\mathrm{Fe}^{2+}$ complexes

Thr total antioxidant content of sago baruk starch with several extractions was presented in Figure 3. In this study indicates that the sago baruk type of starch I have a total antioxidants content that are significantly higher than starch II and starch $\mathrm{K} \quad(\mathrm{p}<0,05)$. The high of total antioxidant starch I show more rich content of antioxidant compounds that can reduce $\mathrm{Fe}^{3+}$ to $\mathrm{Fe}^{2+}$ than starch $\mathrm{K}$ as a comparison. A reducing compound or a reducing agent that is contained in starch baruk powder be classified in natural antioxidants. The total antioxidant content of starch baruk at various concentrations can be seen in Figure 3.

The total antioxidants content of all three types of sago baruk shows increased with increasing concentration, but starch I showed the ability to reduce is highly linear with increasing concentration. There is a tendency all types of the given sago baruk are higher than total antioxidants content. At the same concentration level, starch I shows the highest total antioxidant content than starch II and starch K. Therefore, the presence of phenolic compounds in sago baruk starch can increase antioxidant activity through electron donation and terminate radical chain reaction become more stable products.
Garcia-Salas et al. (2010) suggested that the compounds are classified as natural antioxidants such as phenolic compounds from the class of simple phenolic compounds, flavonoids and tannins. Simple phenolic compounds, flavonoids and tannins are antioxidant compounds that contain phenol structure and have several hydroxyl functional groups are widely found in plants, including sago baruk crop. From this data its was found that the total antioxidant content of all three types of sago baruk starches in line with the total phenolic content. This is due to the phenolic compounds have the ability to reduce $\mathrm{Fe}^{3+}$ to $\mathrm{Fe}^{2+}$ by giving electrons.

\section{Infra Red Spectra}

FT-IR spectrophotometer can be used to estimate the identification of functional groups on sago baruk starch to support chemical analysis data. Starch in sago baruk can be explained by FT-IR spectra. IR spectrum of starch I shows a wide band and strong at the area absorption wave number $3425.58 \mathrm{~cm}^{-1}$ are indicated of the hydroxy group $(\mathrm{O}-\mathrm{H})$. Wide band and strong shows hydroxy group bonded through inter-molecular hydrogen bonding (Silverstein et al., 2015). 


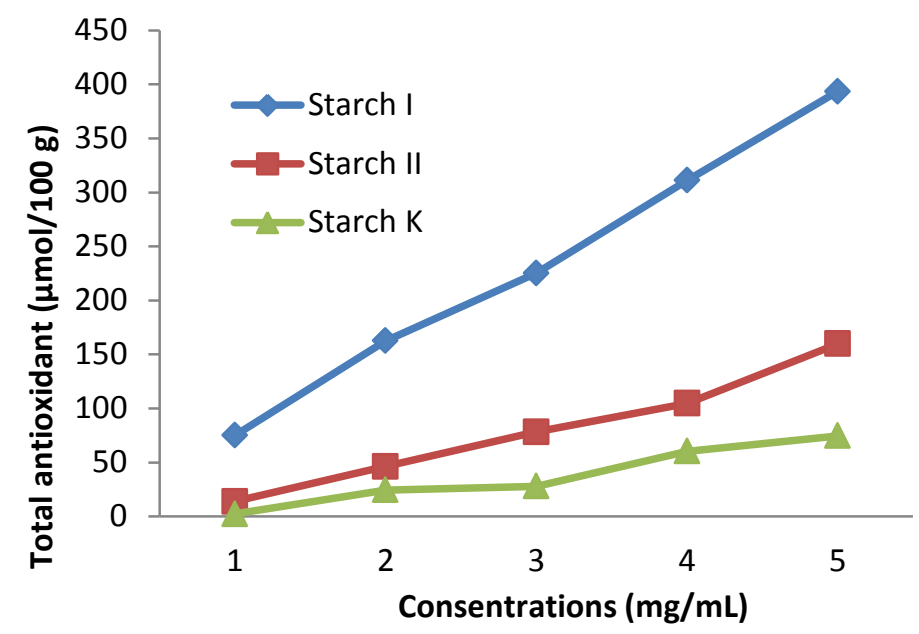

Figure 3. Total antioxidant content of sago baruk starch in various concentration

While the absorbance in area 2931.8 $\mathrm{cm}^{-1}$ indicates the presence of an aliphatic group $(\mathrm{C}-\mathrm{H})$ and absorption at 1658.78 $\mathrm{cm}^{-1}$ region indicates of carbonyl $(\mathrm{C}=\mathrm{O})$. Some signed band glucose as the monomer structure of starch (amylose and amylopectin) identified in the spectral range between 900 and $1400 \mathrm{~cm}^{-1}$ (Leopold et al., 2011). Absorption band in absorbance between the region 900-1153 $\mathrm{cm}^{-1}$ are characteristic of group $\mathrm{C}-\mathrm{O}$ and $\mathrm{C}-\mathrm{C}$, while the absorption in the region $1400-1199 \mathrm{~cm}^{-1}$ due to the group O-C-H, $\mathrm{C}-\mathrm{C}-\mathrm{H}$ and $\mathrm{C}-\mathrm{O}-\mathrm{H}$ which is the strong vibration of their carbohydrates (Irudayaraj and Tewari, 2011). Absorbance between regions from 1373.32 to $1427.32 \mathrm{~cm}^{-1}$ are characteristic of ether group (C-O), $1165 \mathrm{~cm}^{-1}(\mathrm{C}-\mathrm{O})$, $987.55 \mathrm{~cm}^{-1}(\mathrm{C}-\mathrm{H}), 570.93 \mathrm{~cm}^{-1}$ (C-C-O), $401.19 \mathrm{~cm}^{-1}$ (C-C-C). IR spectra analysis for starch II shows characteristics that similar the spectra of starch I. IR spectra of starch II shows absorption at 3446.72 $\mathrm{cm}^{-1}(\mathrm{OH}), 2931,8 \mathrm{~cm}^{-1}(\mathrm{CH}), 1651.07$ $\mathrm{cm}^{-1}(\mathrm{C}=\mathrm{O})$, from 1373.32 to $1427.32 \mathrm{~cm}^{-}$ ${ }^{1}$ (C-O-H), $1165 \mathrm{~cm}^{-1}$ (C-O), $987.55 \mathrm{~cm}^{-1}$ $(\mathrm{C}-\mathrm{H}), 570.93 \mathrm{~cm}^{-1}$ (C-C-O) and 416.62 $\mathrm{cm}^{-1}$ (C-C-C). Similar results were also obtained IR spectra of starch $\mathrm{K}$ showed the absorption at $3417.86 \mathrm{~cm}^{-1}(\mathrm{OH})$, $2931.8 \mathrm{~cm}^{-1}(\mathrm{CH}), 1658.78 \mathrm{~cm}^{-1}(\mathrm{C}=\mathrm{O})$, from 1373.32 to $1427.32 \mathrm{~cm}^{-1}$ (C-O-H),
$1157.29 \mathrm{~cm}^{-1}$ (C-O), $987.55 \mathrm{~cm}^{-1}$ (C-H), $570.93 \mathrm{~cm}^{-1}(\mathrm{C}-\mathrm{C}-\mathrm{O})$ and $416.62 \mathrm{~cm}^{-1}$ (CC-C).

IR spectrum data of starch I, II and starch $\mathrm{K}$ from amylopectin fraction shows that of wavelengths that are relatively similar and have functional groups which are also relatively similar. This means that the three types of sago baruk starch contained the main functional groups are hydroxyl $(\mathrm{OH})$, an aliphatic group $(\mathrm{C}-\mathrm{H})$ and carbonyl $(\mathrm{C}=\mathrm{O})$. Analysis using IR spectrophotometer on the third starch provides a spectrum that similar with amylopectin (Figure 4) as reported by Oktavia et al. (2013) on sweet potato starch. Based on data from the IR spectrum obtained a description that sago baruk starch identified more dominant amylopectin compounds than amylose. These data supported the research results Papilaya et al. (2013) reported that the starch content found on the type Metroxylon rumphii Martius of $71.24 \%$ (70,30\% amylopectin and amylose $29.70 \%$ ) while the type Metroxylon sagus Rottbol of $70,16 \%$ (70.16\% amylopectin and amylose $29.71 \%$ ). Other studies claimed that the sago starch (sago Metroxylon) with cutting age range 9-12 years have a starch content of between 86.88 to $87.25 \%$ (Maherawati et al., 2011). 

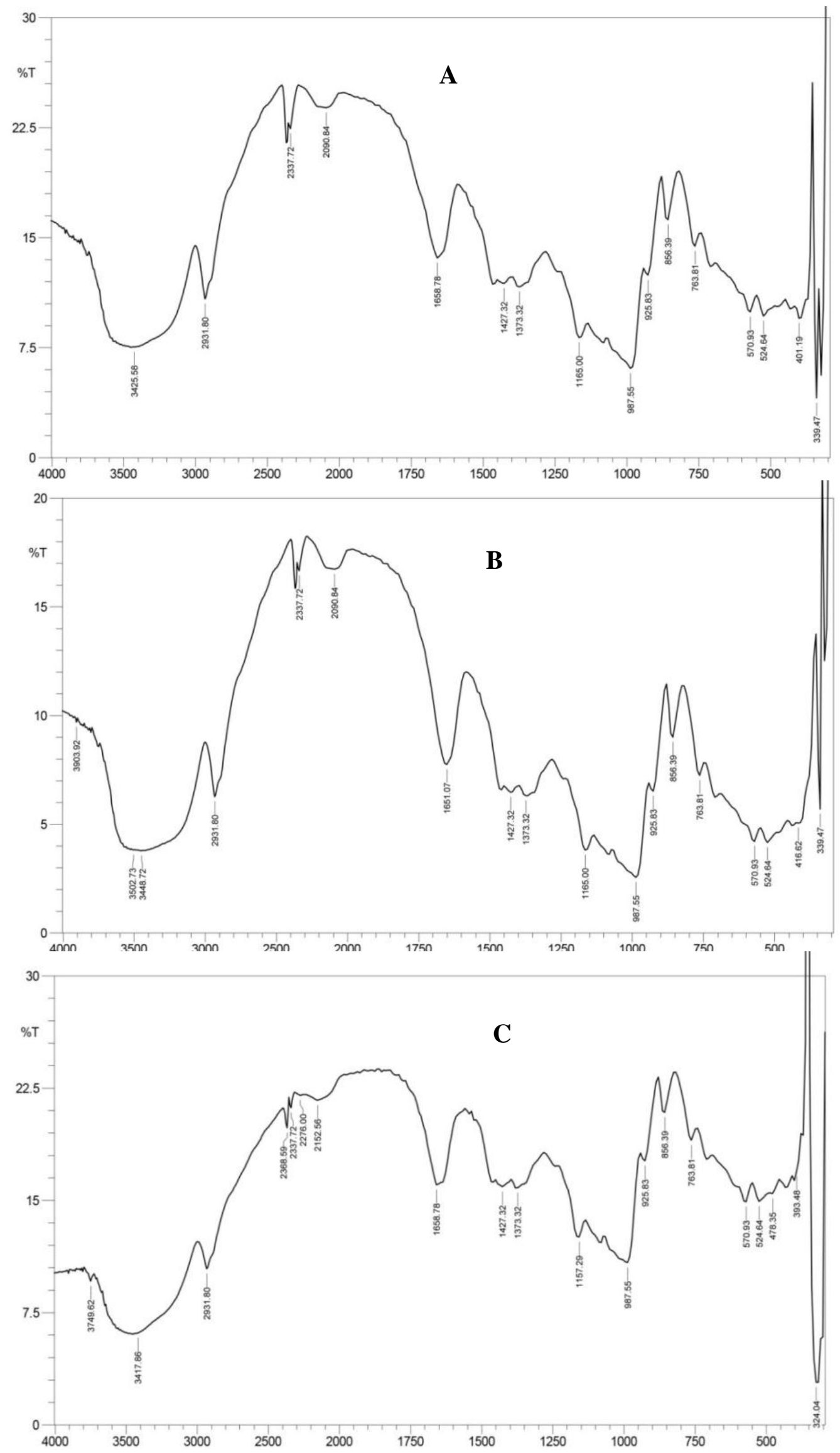

Figure 4. Spectra of 3 type sago baruk (A: starch I, B: starch II and C: starch K) 


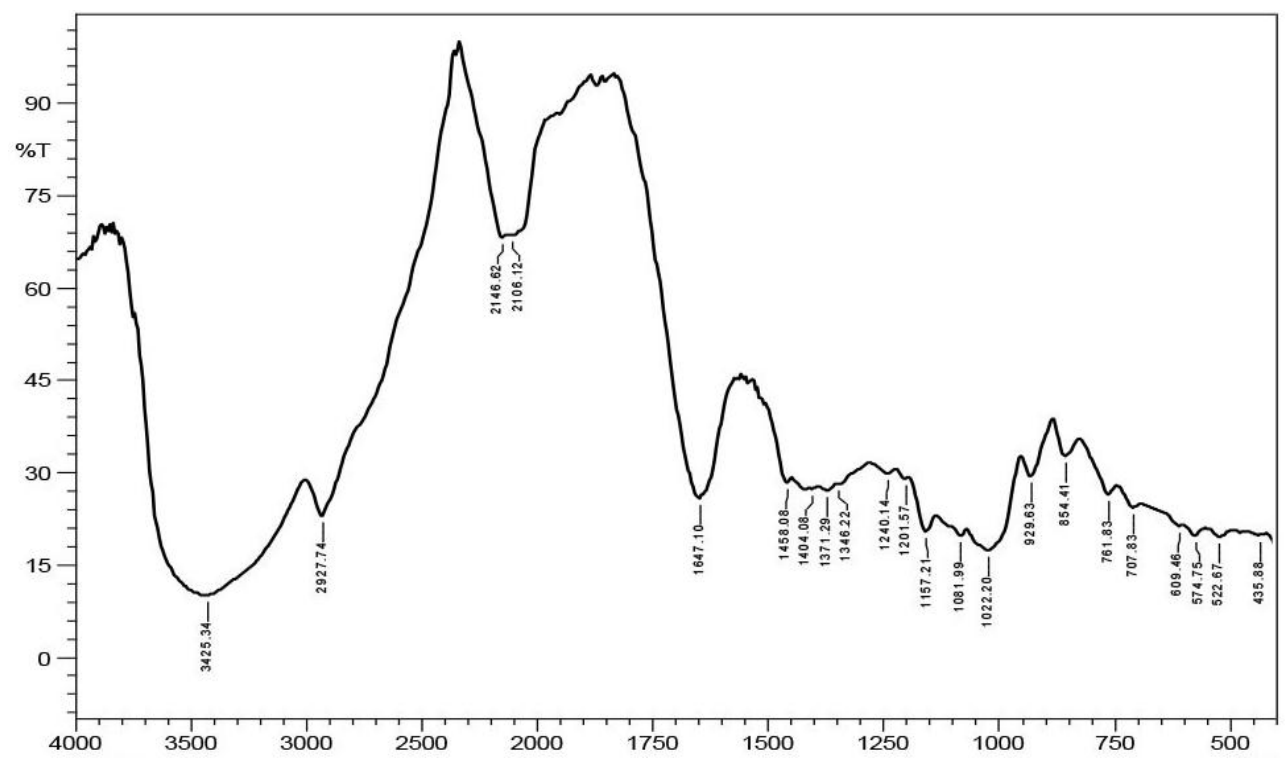

Figure 5. Infra red (IR) spectrum of amylopectin (Oktavia et al., 2013)

\section{CONCLUSION}

Based on the research results obtained, it can be concluded that the chemical characteristics of the sago baruk starch are highly affect the levels proximate (water, protein content, fat content, carbohydrate and fiber content). Starch I extracted sequentially showing phenolic phytochemical content and the highest condensed tannins followed by starch II and starch K. Starch I have the highest antioxidant activity followed by starch II and starch K. Starch I, II and starch $\mathrm{K}$ showed an increase in total phenolic content, condensed tannins and activity of free radical scavengers and total antioxidants in accordance with increasing concentration. Based on data from infra red (IR), sago baruk starch showed absorption at $3425.58 \mathrm{~cm}^{-1}$ (stretching O-H), $2931.8 \mathrm{~cm}^{-1}$ (stretching $\mathrm{C}-\mathrm{H}$ ), $1658.78 \mathrm{~cm}^{-1}$ (stretching $\mathrm{C}=\mathrm{O}$ ), $1165.21 \mathrm{~cm}^{-1}$ (stretching C-O), $570.93 \mathrm{~cm}^{-}$ 1 (stretching C-C-O) and $401.19 \mathrm{~cm}^{-1}$ (stretching C-C-C).

\section{AKNOWLEDGEMENTS}

The author great thank full to the leader of university research improvement: the author would like to thank Chairman Improvement Research Universities: Leading Research Grant
College Year 2015. Directorate of Research and Community Services, Directorate General of Higher Education, Ministry of Education, Research, Technology and Higher Education.

\section{REFERENCES}

Alasalvar, C., Karamac, M., Amarowicz, R \& Shahidi, F. (2006). Antioxidant and antiradical activities in extracts of hazelnut kernel (Corylus avellana L.) and helzelnut green leafy cover. Journal of Agricultural and Food Chemistry. 54(13), 4826-4832.

Alothman, M., Bhat, R. \& Karim, A.A. (2009). Antioxidant capacity and phenolic content of selected tropical fruits from Malaysia, extracted with different solvents. Food Chemistry. 115(3), 785-788.

AOAC (Association of Official Analytical Chemists). (2000). Official Methods of Analysis Chemistrys, The Scientific Association Dedicated to Analytical Excellence, 17th edition, William Horwitz (Ed), Vol 1-2, Washington D.C.

Barros, L., Ferreira, M-J., Queiro, B., Ferreira, I.C.F.R. \& Baptista, P. (2007). Total phenols, ascorbic acid, b-carotene and lycopene in Portuguese wild edible mushrooms 
and their antioxidant activities. Food Chemistry. 103 (2), 413-419

Cornago, D.F., Rumbaoa, R.G.O. \& Geronimo, I.M. (2011). Philippine Yam (Dioscorea spp.) Tubers Phenolic Content and Antioxidant Capacity. Philippine Journal of Science. 140(2), 145-152.

Garcia-Salas, P., Morales-Soto, A., Segura-Carretero, A. \& FernándezGutiérrez, A. (2010). PhenolicCompound-Extraction Systems for Fruit and Vegetable Samples. Molecules, 15, 8813-8826

Irudayaraj, J. \& J. Tewari. (2003). Simultaneous Monitoring of Organic Acids and Sugars in Fresh and Processed Apple Juice by Fourier Transform InfraredAttenuated Total Reflection Spectroscopy Applied Spectroscopy. 57(12), 1599-1604.

Lay, A. \& Indrawanto, C. (2013). Status dan potensi sagu baruk untuk pangan dan konservasi lahan. Persfektif. 12(3), 65-77.

Leopold, L.F., Leopold., N., Diehl, H.A. \& Socaciu, C. (2011). Quantification of carbohydrates in fruit juices using FTIR spectroscopy and multivariate analysis. Spectroscopy. 26, 93-104

Li, X.C., Wu, X.T. \& Huang, L. (2009). Correlation between Antioxidant Activities and Phenolic Contents of Radix Angelicae Sinensis (Danggui). Molecules. 14, 53495361.

Li, X.C., Lin, J., Gao, Y., Han, W. \& Chen, D. (2012). Antioxidant ability and mechanism of Rhizoma Atractylodes macrocephala. Molecules. 17, 13457-13472

Marianus. (2014). The Analysis Production and Chemical Composition Flour of Sagu Baruk Palm (Arenga microcarpha Becc) According to Variation of Altitudes above Sea Level. International
Journal of Agriculture Innovations and Research. 3(3), 2319-1473

Manan, D.M.A. (2011). Optimisation of sago starch extraction using drum rasper. in proceedings of The $10^{\text {th }}$ International Sago Symposium: Sago for food security, bio-energy, and industry from research to market. ISSN: 2089-1202.

Meherawati, Lestari, R.B. \& Haryadi. (2011). Karateristik pati dari batang sagu Kalimantan Barat pada Tahap pertumbuhan yang berbeda. AGRITECH. 31(1), 9-13.

Momuat, L.I., Suryanto, E., Rantung, O., Korua, A. \& Datu, H. (2015). Perbandingan senyawa fenolik dan aktivitas antioksidan antara sagu baruk segar dan sagu baruk kering. Chemistry Progress. 8(1), 20-29

National Standardization Agency of Indonesia. (2008). Sago flour (SNI 3729:2008), Jakarta.

Oktavia, A.D., Idiawati1, N. \& Destiarti, L. (2013). Studi awal pemisahan amilosa dan amilopektin pati ubi jalar (Ipomoea batatas Lam) dengan variasi konsentrasi n-butanol. Jurnal Kimia Khatulistiwa. 2(3), 153-156.

Papilaya, M., Suryanto, E. \& Djakasi, G.S.S. (2013). Karateristik fisik dan kimia tepung sagu dari dua jenis sagu (Metroxylon sp.). Jurnal Ilmu dan Teknologi Pangan. 1(2), 18-23.

Polnaya, F.J., Talahatu, J., Haryadi \& Marseno, D.W. (2009). Karakterisasi Tiga Jenis Pati Sagu (Metroxylon sp.) Hidroksipropil. AGRITECH. 29(2), 58-65.

Shahidi, F., Alasalvar, C. \& LiyanaPathirana, C.M. (2007). Antioxidant phytochemicals in hazelnut kernel (Corylus avellana L.) and hazelnut byproduct. Journal of Agricultural and Food Chemistry. 55(4), 12121220.

Silverstein, RM., Bassler, G.C. \& Morrill, T.C. (2015). Spectrometric Identification of Organic 
Compounds. John Wiley and Sons, Inc. New York.

Suryanto, E. \& Papilaya, M. (2013). Komposisi Fenolik Dan Aktivitas Antioksidan dari 6 Jenis Tanaman Sagu (Metroxylon sagu Rottb). Proseding. Seminar Nasional Kimia Terapan Indonesia. Solo.

Suryanto, E., Momuat, L.I. \& Taroreh, M. (2011). Potensi Senyawa Polifenol Antioksidan dari Pisang Goroho (Musa sapien Sp.). AGRITECH. 31(4), 289-296
Szydlowska-Czerniak, A., Dianoczki, C., Recseg, K., Karlovits, G. \& Szlyk, E. (2008). Determination of antioxidant capacities of vegetable oils by ferric-ion spectrophotometric methods. Talanta. 76 (4), 899-905

Teja, W.A., Sindi, P.I., Ayucitra, A. \& Setiawan. L.E.K. (2008). Karakteristik pati sagu dengan metode modifikasi asetilasi dan cross-linking. Jurnal Teknik Kimia Indonesia. 7(3), 836-843. 